\title{
Determinan Variasi Klaim Penyakit Stroke Peserta Jaminan Kesehatan Nasional Rumah Sakit X Sumatera Utara
}

\section{Determinants of the Claim Variation for Stroke Patient who Covered by National Health Care Insurance at X Public Hospital}

\author{
Joan Xaveria Mahulae', Jaslis Ilyas \\ ${ }^{1}$ Pascasarjana Ilmu Kesehatan Masyarakat, Fakultas Kesehatan Masyarakat, Universitas Indonesia, Depok, Indonesia \\ ${ }^{2}$ Departemen Administrasi dan Kebijakan Kesehatan, Fakultas Kesehatan Masyarakat, Universitas Indonesia, Depok, Indonesia \\ Korespondensi: Joan Xaveria Mahulae, \\ e-mail: joan.xaveria@gmail.com
}

\begin{abstract}
Abstrak
Penelitian yang dilakukan oleh IHME pada tahun 2010 terkait Global Burden of Disease menunjukkan bahwa stroke merupakan penyebab kematian terbesar di Indonesia. Pembiayaan penyakit stroke oleh BPJS Kesehatan menduduki peringkat kedua terbesar setelah penyakit jantung. Penelitian ini ditujukan untuk mengetahui karakteristik dominan yang memicu variasi klaim pasien stroke rawat inap peserta JKN di RS X Sumatera Utara Penelitian ini merupakan penelitian kuantitatif dengan rancangan cross sectional dan analisis multivariat dengan uji regresi linear. Karakteristik yang dominan berhubungan dengan total klaim pasien stroke adalah kelas perawatan ( $p$-value=0,0005), jenis kepesertaan ( $p$-value $=0,0005$ ), lama hari rawat ( $p$-value $=0,004)$, dan tingkat keparahan ( $p$-value =0,0005).

Kata Kunci: stroke, biaya klaim penyakit stroke rawat inap, pengadaan alat medis
\end{abstract}

\begin{abstract}
Refers to IHME study in 2010 about Global Burden of Disease shows that stroke is one of the highest cause of mortality in Indonesia. While the expenditure by BPJS Health for stroke is the $2^{\text {nd }}$ highest after heart disease. This study aims to determine the most dominant characteristics associated with the total claims of stroke patients covered by JKN for inpatient service at X Hospital by doing multivariate analysis with variable linear regression method. The most significant characteristics are type of health care, type of membership, length of stay age, and level of severity. The finding shows that X Hospital is still not optimal in providing services for stroke. Some feasible efforts that can be considered are increasing the neurovascular experts and providing better diagnostic equipments in order to deliver the necessary treatment.
\end{abstract}

Keywords: stroke, cost of claims of inpatient stroke, providing of better diagnostic equipments

\section{Pendahuluan}

Stroke merupakan merupakan suatu kondisi defisit neurologis yang terjadi mendadak sebagai akibat iskemia atau hemoragi sirkulasi saraf otak. Dalam konteks makro, penyakit ini berdampak pada beban pembiayaan kesehatan, mortality, dan morbidity. Stroke merupakan penyakit penyebab kematian terbesar di Indonesia dengan proporsi penyakit diatas umur 15 tahun sebesar 12,1\% (Kemenkesa, 2013).

Data profil statistik Indonesia pada tahun 2012 menunjukan bahwa stroke merupakan penyebab tertinggi kematian dengan proporsi sekitar 21,2\%, dilanjutkan penyakit jantung $(8,9 \%)$, diabetes mellitus $(6,5 \%)$, infeksi saluran pernapasan $(5,2 \%)$, tuberkulosis $(4,3 \%)$ dan penyakit tidak menular lainnya (WHO, 2015). Selain itu, Pusat Data dan Informasi Kemenkes RI tahun 2014 mengungkapkan bahwa sekitar 51\% kematian disebabkan oleh penyakit stroke (Kemenkesb). Penyakit jantung koroner dan stroke diperkirakan akan terus meningkat mencapai 23,3 juta kematian pada tahun 2030 . sejak 1 Januari 2014, bersamaan dengan dimulainya JKN, semua program jaminan kesehatan yang telah dilaksanakan pemerintah (Askes, Jamsostek, Jamkesmas dll) diintegrasikan dalam satu badan yaitu BPJS Kesehatan. Pemerintah bertanggungjawab untuk membayar iuran JKN bagi masyarakat miskin dan tidak mampu yang terdaftar sebagai peserta Penerima Bantuan Iuran (PBI) (TNP2K, 2015). Berdasarkan laporan pengelolaan program tahun 2015 dan laporan keuangan 2015, hingga akhir tahun 2015 jumlah peserta BPJS mencapai 156.790.287 jiwa. Bersamaan dengan meningkatnya jumlah peserta maka jumlah biaya pelayanan kesehatan yang dikeluarkan oleh BPJS juga mengalami peningkatan. Di dalam laporan BPJS 2015, dinyatakan bahwa biaya pengeluaran pelayanan kesehatan mencapai Rp. 57,08 triliun dengan peningkatan dari tahun ke tahun.

Dari total pengeluaran BPJS untuk pembiayaan kesehatan, penyakit katastropik (penyakit ber- 
biaya tinggi) dipandang sebagai beban yang banyak menyerap dana JKN dan menjadi salah satu penyebab BPJS Kesehatan terus defisit. Biaya penyakit katastropik menyedot sekitar 30\% atau sekitar Rp. 16,9 triliun dari anggaran JKN. Penyakit katastropik yang harus ditangung terdiri dari penyakit jantung (13\%), gagal ginjal kronik (7\%), kanker (5\%), stroke $(2 \%)$, thalasemia $(1 \%)$, haemofilia $(0,2 \%)$ dan leukemia (0,3\%) (Kemenkesc, 2016).

Sebagai Fasilitas Kesehatan Rujukan Tingkat Lanjutan (FKRTL), Rumah Sakit Umum (RSU) Tarutung melayani pasien dengan penyakit yang didominasi oleh penyakit degeneratif. Pada tahun 2015, data pasien stroke rawat inap RS X Sumatera Utara menunjukkan peningkatan sebesar 50\% dari tahun sebelumnya. Sebagai satu-satunya rumah sakit di daerah kabupaten tersebut penanganan terhadap penyakit stroke menjadi penting untuk ditelaah karena mempengaruhi besarnya beban biaya BPJS Kesehatan.

Merujuk pada kerangka cakupan universal yang dikemukakan oleh WHO, terdapat beberapa dimensi yang menjadi tolak ukur, antara lain (i) jumlah penduduk yang dijamin yaitu jika seluruh penduduk memiliki jaminan kesehatan dari penyakit katastropik; (ii) jenis layanan yaitu terkait dengan paket manfaat yang diperoleh peserta untuk menjamin kebutuhan dasar kesehatan; (iii) dimensi tinggi (biaya dari kantong sendiri) yaitu dijadikan ukuran protektabilitas sejauh mana penduduk dilindungi dari pemiskinan akibat penyakit yang dideritanya (World Bank, 2015).

Utilisasi pelayanan kesehatan pada prinsipnya mempengaruhi besarnya biaya pelayanan kesehatan. Teori pemanfaatan pelayanan kesehatan menurut Anderson menjadi kerangka konsep penelitian ini. Variabel independen dalam penelitian ini adalah umur, jenis kelamin, jenis kepesertaan, lama hari rawat atau LOS (length of stay), kriteria tindakan, asal admisi, tingkat keparahan, kriteria rujukan dan kelas perawatan sedangkan variabel dependen adalah biaya penyakit stroke. Oleh karena itu penelitian ini dilakukan untuk melihat karakteristik yang paling berhubungan dengan biaya klaim pasien stroke rawat inap peserta JKN yang dilakukan di RS X Sumatera Utara.

\section{Metodologi Penelitian}

Penelitian ini menggunakan pendekatan kuantitatif dengan rancangan cross sectional untuk mengidenti- fikasi variasi klaim JKN di RS X Sumatera Utara pada tahun 2016. Analisis dilakukan dengan metode regresi linear berganda untuk menentukan faktor dominan yang paling berhubungan terhadap biaya penyakit stroke rawat inap pada pasien JKN di RS X Sumatera Utara. Proses pengambilan data dilakukan dari bulan April hingga Mei 2017.

Populasi dalam penelitian ini adalah seluruh peserta JKN stroke yang telah mendapatkan pelayanan kesehatan di RS X Sumatera Utara. Proporsi populasi pasien stroke rawat inap tahun 2016 sebesar $9 \%$ dan perkiraan pasien stroke dengan JKN sebesar $6 \%$. Perhitungan sampel yang dilakukan menggunakan rumus:

$$
n=\frac{z^{2}{ }_{1-\alpha / 2}^{*} p^{*}(1-p)}{d^{2}}
$$

Keterangan:

$\mathrm{p}=$ perkiraan proporsi

$\mathrm{d}=$ presisi : $1 \%, 5 \%, 10 \%$

$\mathrm{z}=$ nilai $\mathrm{z}$ pada interval kepercayaan $(1-\mathrm{a} / 2)$ : tingkat kepercayaan yaitu 95\%, $z=1,96$

Sampel dari populasi studi sebesar 90 data klaim dengan unit analisis individu peserta JKN yang terdaftar sebagai pasien rawat inap penyakit stroke. Analisis data yang dilakukan menggunakan analisis univariat, bivariat hingga multivariat dengan uji regresi linear berganda. Kendala saat dilakukan uji normalitas pada variabel biaya menunjukkan bahwa variabel biaya tidak terdistribusi normal. Oleh karena itu, dilakukan transformasi data pada variabel biaya dengan jenis transformasi square root (akar) sehingga didapatkan data variabel biaya yang terdistribusi normal. Pada variabel independen juga dilakukan transformasi sehingga variabel mempunyai skala ukur interval.

\section{Hasil Penelitian}

Hasil analisis univariat menunjukkan rata-rata tarif INA-CBG's pasien stroke sebesar Rp 4.290.000 dengan standar deviasi Rp 1.133.000 (Tabel 1). Tarif terendah adalah Rp 2.906.500 dan tertinggi Rp 7.094.800 dengan rata-rata lama hari rawat pasien stroke adalah 5,79 hari atau 6 hari. Hari yang paling singkat adalah 0 hari atau 1 hari (pasien langsung dirujuk atau meninggal) dan yang terlama adalah 14 hari.

Lama hari rawat inap pasien stroke di RS X Sumatera Utara masih termasuk dalam fase akut yai- 
Tabel 1. Distribusi Umur dan Length of Stay dan Tarif INA CBGs Pasien Stroke di RS X Sumatera Utara Tahun 2016

\begin{tabular}{cccc}
\hline Variabel & Umur & Length of Stay & Tarif INA-CBGs \\
\hline Mean & 63,96 & 5,79 & 4.290 .000 \\
\hline Median & 64,00 & 5,50 & 4.070 .000 \\
\hline Standar Deviasi & 12,23 & 3,2 & 1.133 .000 \\
\hline Min-Max & $34-89$ & $0-14$ & $2.906 .500-7.094 .800$ \\
\hline $95 \%$ CI & $61,39-66,52$ & $5,12-6,46$ & $4.050 .000-4.530 .000$ \\
\hline
\end{tabular}

tu $<43$ hari sehingga pembiayaan pasien oleh rumah sakit disesuaikan dengan tarif hasil grouping INA-CBG versi 4.0. Perhitungan tarif pasien dengan lama hari rawat 43 - 103 hari akan berbeda karena merupakan kasus sub akut dengan perhitungan tarif berdasarkan akumulasi tarif fase akut dengan top up payment fase sub akut.

Deskripsi variabel umur yang diperoleh menunjukkan rata-rata umur pasien rawat inap penyakit stroke sekitar 64 tahun dengan standar deviasi 12,23 tahun. Ditemukan pasien dengan umur termuda adalah 34 tahun dan umur paling tua adalah 89 tahun (Tabel 1).

Karakteristik sampel dalam penelitian terdiri dari usia, jenis kelamin, jenis kepesertaan, lama hari rawat, kelas perawatan, asal admisi, kriteria rujukan, kriteria tindakan, tingkat keparahan dan variabel terikat biaya penyakit stroke rawat inap berdasarkan tarif INA CBG's. Variabel yang diukur adalah data klaim dari 90 pasien rawat inap penyakit stroke dengan JKN dari keseluruhan jumlah penderita penyakit stroke JKN sebanyak 128 orang dalam kurun waktu satu tahun. Adapun hasil pengukuran variabel berdasarkan karakteristik diperlihatkan pada tabel 2 .

Tabel 2 menunjukkan bahwa pasien stroke di rawat inap berjumlah 90 pasien dari total pasien 128 orang dan sebagian besar berumur dewasa menuju lansia (>60). Untuk jenis kepesertaan cenderung didomasi oleh PBI dan selaras dengan distribusi kelas perawatan yang didominasi oleh kelas 3 (tiga) rawat inap. Sampel diperoleh dari penelusuran rekam medis pasien stroke JKN yang disertai formulir verifikasi koder dengan acuan data dari unit rekam medis.

Data total pasien stroke dengan JKN sebesar
34\% dari total seluruh pasien stroke rawat inap tahun 2016. Berdasarkan hasil uji analisis bivariat, karakteristik yang berhubungan dengan biaya klaim pasien stroke rawat inap peserta JKN yang dilakukan di RS X Sumatera Utara adalah jenis kepesertaan $(\mathrm{p}$-value $=0,0005)$, kelas perawatan $(\mathrm{p}$-value $=0,0005)$, lama hari rawat $(\mathrm{p}-$ value $=0,004)$, dan tingkat keparahan $(\mathrm{p}$-value $=0,0005)$.

Pengelompokan dalam INA-CBGs menggunakan sistem kodifikasi dari diagnosis akhir dan tindakan/ prosedur yang menjadi output pelayanan, dengan acuan ICD-10 untuk diagnosis dan ICD-9-CM untuk tindakan/prosedur. Dalam hal ini penggolongan kriteria tindakan dalam INA-CBGs berdasarkan prosedur operasi dan prosedur non operasi. Adapun kriteria tindakan yang dimaksud dalam penelitian ini adalah prosedur non operatif yang berupa tindakan terapi seperti oksigen terapi, nebulizer, pemasangan NGT, dan pemasangan folley kateter yaitu sebanyak 60 orang. Jumlah pasien yang hanya mendapatkan terapi medikasi adalah sebanyak 30 orang. Oleh karena itu dapat disimpulkan bahwa tindakan yang diterima oleh pasien stroke JKN di RS X Sumatera Utara hanya berupa tindakan non operatif.

\section{Analisis Multivariat}

Untuk mengetahui variabel yang paling berhubungan dengan biaya kesehatan terhadap pelayanan rawat jalan, maka dilakukan uji regresi linear seluruh variabel independen. Variabel yang dapat dianalisis lanjutan yaitu variabel yang mempunyai p-value < 0,25 . Oleh karena itu variabel yang selanjutnya akan dianalisis kedalam multivariat adalah variabel umur, jenis kepesertaan, kelas perawatan, lama hari rawat dan tingkat keparahan. Setelah dilakukan uji mul- 
Tabel 2. Distribusi Hubungan Karakteristik dan Pembiayaan Pasien Rawat Inap Penyakit Stroke di RS X Sumatera Utara Tahun $2016(\mathrm{n}=90)$

\begin{tabular}{|c|c|c|c|c|c|}
\hline Variabel & $\mathbf{F}$ & $\%$ & Mean & Standar Deviasi & $P$ Value \\
\hline \multicolumn{6}{|l|}{ Umur } \\
\hline 30-59 tahun & 35 & 38,9 & 4.113 .497 & 68.662 & \multirow{3}{*}{0,100} \\
\hline 60-69 tahun & 26 & 28,9 & 3.981 .710 & 56.394 & \\
\hline >70tahun & 29 & 32,2 & 4.578 .872 & 81.004 & \\
\hline \multicolumn{6}{|l|}{ Jenis Kelamin } \\
\hline Laki-laki & 42 & 46,7 & 4.278 .006 & 78.811 & \multirow{2}{*}{0,653} \\
\hline Perempuan & 48 & 53,3 & 4.172 .842 & 65.801 & \\
\hline \multicolumn{6}{|l|}{ Jenis Kepesertaan } \\
\hline PBI & 32 & 35,6 & 3.466 .605 & 37.637 & \multirow{4}{*}{$0,0005^{\star *}$} \\
\hline PPU & 13 & 14,4 & 4.490 .361 & 68.833 & \\
\hline PBPU & 19 & 21,1 & 4.429 .634 & 36.585 & \\
\hline $\mathrm{BP}$ & 26 & 28,9 & 4.943 .035 & 66.291 & \\
\hline \multicolumn{6}{|l|}{ Kelas Perawatan } \\
\hline Kelas 3 & 41 & 45,6 & 3.605 .387 & 43.698 & \multirow{3}{*}{$0,0005^{\star *}$} \\
\hline Kelas 2 & 22 & 24,4 & 4.448 .376 & 44.734 & \\
\hline Kelas 1 & 27 & 30,0 & 5.049 .410 & 61.155 & \\
\hline \multicolumn{6}{|l|}{ Lama Hari Rawat } \\
\hline 9-14 hari & 22 & 23,7 & 4.822 .039 & 64.073 & \multirow{4}{*}{$0,004^{\star *}$} \\
\hline 6-8 hari & 23 & 24,7 & 4.251 .216 & 82.105 & \\
\hline 3-5 hari & 29 & 31,2 & 4.132 .968 & 67.005 & \\
\hline $0-2$ hari & 16 & 17,2 & 3.570 .554 & 28.056 & \\
\hline \multicolumn{6}{|l|}{ Kriteria Tindakan } \\
\hline Ada Prosedur & 60 & 64,5 & 4.230 .964 & 73.732 & \multirow{2}{*}{0,911} \\
\hline Tidak ada Prosedur & 30 & 32,2 & 4.203 .370 & 68.535 & \\
\hline \multicolumn{6}{|l|}{ Tingkat Keparahan } \\
\hline Berat & 7 & 7,8 & 5.626 .989 & 37.796 & \multirow{3}{*}{$0,0005^{* *}$} \\
\hline Sedang & 43 & 47,8 & 4.675 .833 & 59.174 & \\
\hline Ringan & 40 & 44,4 & 3.547 .150 & 32.021 & \\
\hline \multicolumn{6}{|l|}{ Kriteria Rujukan } \\
\hline Rujukan & 15 & 16,1 & 4.171 .055 & 26.584 & \multirow{2}{*}{0,782} \\
\hline Tidak Rujukan & 75 & 80,6 & 4.231 .932 & 80.590 & \\
\hline \multicolumn{6}{|l|}{ Asal Admisi } \\
\hline UGD & 86 & 95,6 & 4.212 .355 & 69.363 & \multirow{2}{*}{0,805} \\
\hline Klinik & 4 & 4,4 & 4.426 .395 & 144.206 & \\
\hline
\end{tabular}

\footnotetext{
* = bermakna signifikan secara statistik (p-value $<0,05)$
}

** = bermakna signifikan secara statistik $(\mathrm{p}$-value $<0,01)$ 
Tabel 3. Pemodelan Terakhir Multivariat

\begin{tabular}{llccccc}
\hline Variabel & P-value & Koefisien B & $\begin{array}{c}\text { Koefisien } \\
\text { Beta }\end{array}$ & r & $\mathrm{R}^{2}$ & $\begin{array}{c}\text { P value } \\
\text { Model }\end{array}$ \\
\hline Constant & 0.000 & 2197.194 & & & & \\
1. Umur & 0.381 & 22.507 & 0.071 & & & \\
2. Jenis Kepesertaan & 0.079 & 41.373 & 0.193 & & & \\
3. Lama Hari Rawat & 0.285 & -20.143 & -0.079 & 0.791 & 0.625 & \\
4. (LOS) & 0.000 & 110.026 & 0.355 & & & \\
5. Kelas Perawatan & 0.000 & -212.086 & -0.498 & & & \\
\hline
\end{tabular}

tivariat berikut ini merupakan pemodelan terakhir multivariat (Tabel 3).

Berdasarkan koefisien B masing-masing variabel independen pada pemodelan terakhir multivariat didapatkan persamaan regresi sebagai berikut:

Biaya Rawat Inap $=2197,19+22,5$ Umur $+41,3$ Jenis Kepesertaan - 20,1 LOS + 110 Kelas perawatan - 212 Tingkat Keparahan

Persamaan multivariat diatas memiliki koefisien determinasi ( $R$ square) yang menunjukkan nilai 0,625 artinya bahwa model regresi yang diperoleh dapat menjelaskan 62,5\% variasi dependen biaya klaim penyakit stroke. Dengan kata lain kelima variabel independen tersebut dapat menjelaskan variasi variabel biaya klaim sebesar 62,5\% (Tabel 3). Dalam analisis multivariat sudah memenuhi uji asumsi. Berdasarkan hasil koefisien beta didapatkan bahwa variabel yang paling besar pengaruhnya pada determinan variasi klaim penyakit stroke adalah kelas perawatan.

\section{Pembahasan}

\section{Rata-rata Biaya Penyakit Stroke Pasien Rawat} Inap dan Karakteristik Peserta

Karakteristik pasien yang memiliki hubungan yang signifikan dengan biaya klaim penyakit stroke adalah variabel jenis kepesertaan, lama hari rawat, kelas perawatan, dan tingkat keparahan. Variabel tersebut telah dianalisis dengan uji anova dan hasil p value < 0,005 . Karakteristik usia digolongkan berdasarkan pedoman WHO.

Penyakit Stroke pada dasarnya bukan merupakan penyakit yang didominasi oleh jenis kelamin tertentu. Beberapa penelitian yang memperlihatkan adanya kecenderungan gender. Penelitian di Kotamadya Bogor ditemukan penderita stroke laki-laki $(76,8 \%)$ lebih banyak dibandingkan perempuan $(23,2 \%)$ (Kusuima et al, 2009). Data Riskesdas 2013 juga menunjukkan bahwa prevalensi penyakit stroke pada jenis kelamin laki-laki $(7,1 \%)$ lebih besar dari perempuan $(6,8 \%)$. Namun hal ini berbeda dengan hasil penelitian di RS X Sumatera Utara menunjukkan bahwa jumlah pasien stroke didominasi perempuan dengan perbandingan $8: 7$.

Pembiayaan penyakit stroke pada jenis kelamin laki-laki lebih tinggi sebesar Rp 4.278.006 dibandingkan perempuan sebesar Rp 4.172.842. Hal ini dapat disebabkan oleh karena tingkat keparahan pasien stroke pada jenis kelamin laki-laki lebih tinggi dari perempuan. Hasil penelitian OECD (Organisation for Economic Co-operation and Development) (2016) di Belanda juga menunjukkan bahwa jenis kelamin laki-laki cenderung mengalami gangguan sirkulasi seperti penyakit stroke sementara perempuan cenderung menderita penyakit sistem saraf seperti dimensia, dan depresi. Dengan demikian, dapat disimpulkan bahwa tingkat keparahan penyakit stroke pada jenis kelamin laki-laki akan lebih tinggi dibanding perempuan. Oleh karena itu, perlu dieksplorasi variabel yang mempengaruhi tingkat keparahan dari gaya hidup gender.

Pelayanan pasien JKN yang berobat ke rumah sakit harus menunjukkan bukti kepesertaan BPJS Kesehatan. Data yang tercantum dalam rekam medis berupa surat eligibilitas pasien yang menunjukkan jenis keanggotaan JKN. Jumlah pasien dengan jenis kepesertaan PBI mendominasi pasien stroke di RSU Taruntung dengan rata-rata pembiayaan per klaim sebesar Rp. 3.466.605. Hal ini disebabkan karena disebabkan karena didominasi peserta PBI yang mendapatkan perawatan di kelas 3 sehingga tarif yang ditanggung BPJS cukup rendah.

Kriteria pasien pulang dengan diagnosa penyakit stroke didominasi dengan kriteria pulang berobat jalan (PBJ) dan diikuti dengan kriteria pasien rujukan. Hal ini sesuai dengan tingkat keparahan penyakit stroke yang tidak disertai dengan komorbiditi atau penyakit penyerta. Rata-rata biaya pasien dengan kriteria rujukan sebesar Rp 4.171.055 
sementara kriteria pasien tidak dirujuk sebesar Rp 4.231.932. Dari data tersebut dapat disimpulkan bahwa pasien dengan kriteria tidak dirujuk menunjukkan pembiayaan yang lebih besar dibandingkan dengan pasien yang dirujuk. Selisih biaya yang ada memang tidak menunjukkan perbedaan yang jauh karena kode INA- CBGs pada umumnya sama.

\section{Rata-rata Biaya Penyakit Stroke Pasien Rawat} Inap dalam Satu Tahun

Hasil penelitian menunjukkan rata-rata biaya klaim rawat inap pasien stroke dalam satu kali klaim sebesar Rp 4.290.000. Bila dilihat dari regional provinsi Sumatera Utara pada tahun 2015, biaya rata-rata pasien stroke rawat inap di RS tipe B sebesar Rp. 5.395.428. Selisih rata-rata pasien stroke di Provinsi Sumatera Utara dengan pasien stroke di RSUD Tarutung mengindikasikan bahwa pasien stroke di RS X Sumatera Utara memiliki karakteristik pasien dengan kelas perawatan dan tingkat keparahan yang lebih rendah atau karena penetapan diagnosa yang kurang spefisik.

Stroke merupakan penyakit katastropik sebab biaya perawatan yang tinggi dan akibat kecacatan yang timbul apabila penanganannya tidak tepat. Disabiliti merupakan masalah kesehatan masyarakat yang juga menimbulkan beban biaya yang tinggi baik oleh penderita, keluarga masyarakat dan negara. Penelitian di Amerika Serikat pada tahun 2008 menunjukkan bahwa dalam setahun dihabiskan dana sebesar 65,5 milyar dollar untuk membiayai perawatan dan biaya kompensasi penurunan produktivitas yang berhubungan dengan angka kejadian dan kecacatan stroke (Kemenkesd, 2013).

Variabel yang paling berhubungan dengan biaya rawat inap dari analisis statistik adalah kelas perawatan. namun variabel tersebut merupakan variabel yang tidak dapat diintervensi. Hasil penelitian ini juga berbeda dengan pedoman penyusunan tarif INA-CBG yaitu berdasarkan CMG (case main groups), tipe kasus, CBG kasus dan tingkat keparahan. Hal ini disebabkan karena keterbatasan data sekunder yang tersedia dan pengelompokkan pasien stroke yang lebih spesifik sehingga tidak tampak variasi yang bermakna. Selain itu juga karena keterbatasan dokter spesialis dan peralatan diagnostik sehingga penetapan diagnosa cenderung sama.

\section{Kesimpulan}

Ada hubungan antara rata-rata biaya penyakit stroke rawat inap dengan kelas perawatan, jenis kepeserta- an, lama hari rawat, dan tingkat keparahan. Peserta pada usia 30-59 tahun, jenis kelamin perempuan, dengan kelas tiga perawatan merupakan merupakan kelompok terbesar pasien stroke. Karakteristik paling dominan berhubungan dangan biaya klaim penyakit stroke pasien rawat inap adalah kelas perawatan, jenis kepesertaan, umur, lama hari rawat dan tingkat keparahan. Biaya rata-rata penyakit stroke rawat inap RS X Sumatera Utara masih lebih rendah dibandingkan rata-rata rumah sakit kelas B di Sumatera Utara. Beban komplikasi penyakit stroke seperti disabilitas akan lebih besar apabila gejala penyakit stroke tidak dideteksi secara dini.

\section{Daftar Pustaka}

Grebner, Leah A., et. al. 2013. Medical Coding: Understanding ICD-10-CM and ICD-10-PCS. New York: McGraw-Hill.

Kemenkesa. 2013. Riset Kesehatan Dasar tahun 2013. Kementerian Kesehatan Republik Indonesia. Jakarta.

Kemenkesb. 2014. Info Datin: Pusat Data dan Informasi Kemenkes RI - Situasi Kesehatan Jantung. Kementerian Kesehatan Republik Indonesia. Jakarta.

Kemenkesc. 2016. Perkembangan dan tantangan JKN. [25 Oktober 2016]. Kementerian Kesehatan Republik Indonesia. Diakses 18 November 2016 <http://www.depkes.go.id/article/ view/16102600001/-perkembangan-dan-tantangan-implementasi-jkn.html>

Kemenkesd. 2013. Pedoman Pengendalian Stroke. Direktorat Pengendalian Penyakit Tidak Menular Subdit Pengendalian Penyakit Jantung dan Pembuluh Darah Kementerian Kesehatan Republik Indonesia. Jakarta.

Kusuma, Y., et. al. 2009. Burden of stroke in Indonesia. International Journal of Stroke. 4(5): 379-80

OECD. 2016. Estimating Expenditure by Disease, Age and Gender. Organisation for Economic Co-operation and Development. Diakses pada 16 April 2017 <http://www. oecd.org/els/health-systems/ estimating-expenditure-by-disease-age-and-gender.htm>

Peraturan Menteri Kesehatan Republik Indonesia Petunjuk Teknis Sistem Indonesian Case Based Groups (INA-CBGs), PMK RI No. 27 Tahun 2014, BN No.795 Tahun 2014.

Setyopranoto, Ismail. 2011. "Stroke: Gejala dan Penatalaksanaan”. Continuing Medical Education 185, Vol. 38, No.4. 
TNP2K. 2015. Program Jaminan Kesehatan Nasional. Tim Nasional Percepatan Penanggulangan Kemiskinan. Diakses pada 1 November $2016<$ http:// www.tnp2k.go.id/id/tanya-jawab/klaster-i/program-jaminan-kesehatan-nasional-jkn>

WHO. 2015. Indonesia : WHO Statistical Profile. [Januari 2015]. WHO and UN Partners. Diakses
10 November 2016 <http://www.who.int/gho/ countries/ idn.pdf $>$.

World Bank. 2015. Going Universal: 24 Countries and the "How" of Universal Health Coverage. Washington DC: International Bank for Reconstruction and Development. 